\title{
IDENTIFYING THE IMPACT OF INTEGRATING BUILDING INFORMATION MODELING WITH MAINTENANCE MANAGEMENT A LITERATURE REVIEW
}

\author{
Tamer Ahmed Mohamed Hossam, Ali Fathi Eid and Laila Khodeir \\ Faculty of Engineering, Ain Shams, British University, Cairo, Egypt.
}

\begin{abstract}
Building maintenance is considered to be the cornerstone of modern management systems for newly established projects. One of the reasons is that it plays an important role in reducing maintenance cost and increasing the lifetime of project components. However the lack of sufficient studies, lack of awareness and lack of coordination with different disciplines on a project delivery process affect maintenance managers and staff on having accurate and specific information needed for a project components, which leads to waste of resources, time and indirect cost of a project, While technological development gives one of the most popular systems which is known as building information modeling (BIM) as a new tool to support maintenance management. Thus, the main objective of this paper is to identify the impact of integrating building information modeling with maintenance management, whether this integration would be useful for stakeholders or would it help in reducing project budget and save time or not. The research methodology involved a literature review study on this topic. Where it is found that maintenance managers can reach the higher quality and better performance for a project by using BIM tools, data required and process. Furthermore, such integration has proved to be a great value regarding the efficiency of the maintenance management process, eliminating waste of time, rework and sequentially cost reduction.
\end{abstract}

Keywords : Maintenance management; Building Information Modeling (BIM); Construction Operation Building information exchange (COBie); Industrial Foundation Class.

\section{Research Objective}

This paper aims to identify the impact of integrating building information modeling with maintenance management. Whether this integration would be useful for stakeholders and would it help in reducing project budget and save time or not.

\section{Research Methodology}

The paper methodology involved a comprehensive overview through viewing extant literature sources as this topic is considered to be a part of a literature review.

\section{INTRODUCTION}

Maintenance management has become one of the most important factors that help complex buildings to perform effectively. As a result, buildings lifespan has dramatically increased especially when using recent technology. Maintenance management has become more powerful, where building information modeling (BIM) helped in making standards that allows maintenance managers to make sure that every component in the building is working effectively. 
Nowadays, technological development gives new tools, techniques, and systems for the AEC industry. Since BIM is considered one of the most popular systems, that is why it was important to spot the light on this system and its role in supporting maintenance management. In addition, how it improves maintenance management by reducing resources, time and cost of maintenance process of a project. In this regards, this integration shall help to achieve high rates of efficiency and quality of the components in a project.

Thus, the technological development and the presence of BIM provided new chances to make the archiving process easier, cheaper, more accurate and optimum. Where construction operation building information exchange (COBie) is considered to be from the latest developed standard that is integrated with BIM, which supports the information exchange process for any maintenance management and staff work on an operated project from the design and construction phases to the operation phase. Archiving all the components included in a project with accurate and full detailed information, which can be extracted with fewer resources and in a consuming minimum time.

\section{Literature Review}

\subsection{The Maintenance Management Process}

In order to maintain, repair or even replace a component in a building it should be done through a process and decisions taken by maintenance management team, taking in consideration that this decision may affect a building function which means affect the indirect cost of a project through its operational phase, however the maintenance management process can be divided into two parts:

- $\quad$ Maintenance strategy.

- Implementation of Strategy.

\subsubsection{The Definition of Maintenance Strategy}

To define a maintenance strategy, a proper definition of the maintenance objectives as an input needs to be addressed. The definition can be obtained directly from the business plan. This initial part of the maintenance management process shows the success of maintenance in an organization and determines the effectiveness of the subsequent implementation of the maintenance plans, schedules, controls, and improvements.

Effectiveness shows how well a department or function meets its goals or company needs, and it is often discussed in terms of quality of the service provided which is viewed from the customer's/owner's perspective.

This would be able to minimize the maintenance indirect costs, those costs associated with production losses, and ultimately, with customer dissatisfaction. In the case of maintenance, effectiveness can represent the overall company satisfaction with the capacity and condition of its assets, or the reduction of the overall company cost obtained because production capacity is available when needed. Effectiveness concentrates on the correctness of the process and whether the process produces the required result or not [1].

\subsubsection{Implementation of the Strategy}

The second part is the implementation of the selected strategy. The ability to deal with the maintenance management implementation problem, which can allow minimizing the maintenance direct cost (labor and other maintenance required resources). In this part of the process, it deals with the efficiency of the management, which might be less important. Efficiency is acting or producing with minimum waste, expense, or unnecessary effort. 
Efficiency is then understood as providing the same or better maintenance for the same cost. At last, a maintenance management model can be finalized as consisting of eight sequential management building elements, as presented in Figure 1. The first three building elements discuss maintenance effectiveness while the fourth and fifth elements ensure maintenance efficiency. Elements six and seven are devoted to maintain and asset life-cycle cost assessment. Finally, element eight ensures continuous maintenance management improvement [2].

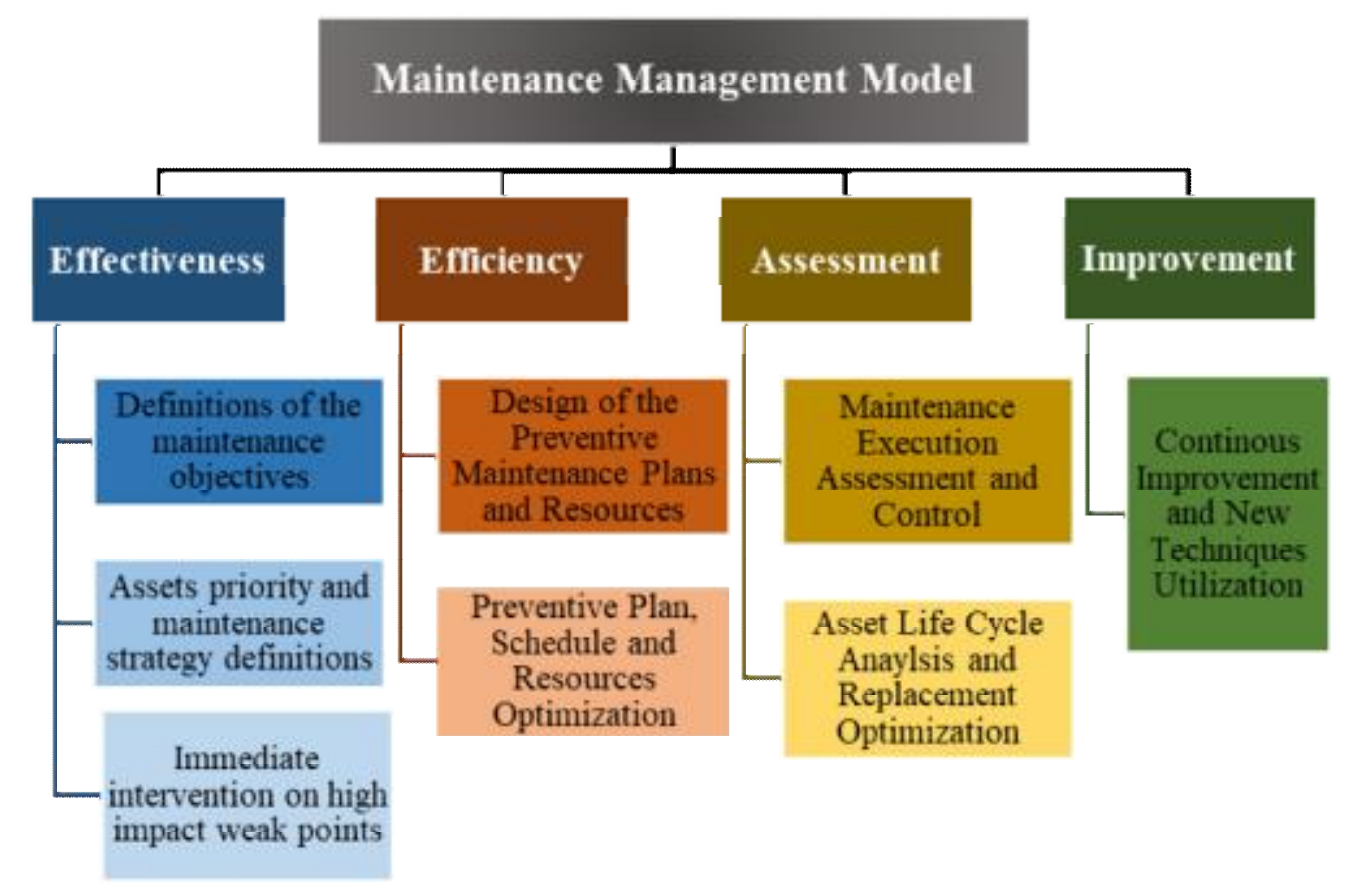

Figure 1. Maintenance management model [1].

Figure 1. shows that maintenance management model consists of four main groups: effectiveness is the first group which consists of three elements. Where the first element concerns the definition of the maintenance objectives and declaration of model goals and maintenance plan which will help to achieve the best technical and financial performance of these objectives.

Moving to the second element in the first group, which is assets priority and maintenance strategy definitions. Where defining the strategic plans needs to achieve model goals mentioned in the first element, taking in consideration the financial, time-wise and quality priorities. Using these assessments will be a guide for the immediate intervention on high impact weak points and how to avoid its effects on our strategic plans which will be the third element in the group.

While the second group spots on Efficiency, this group consists of two elements complied with the main definition of efficiency where the first element is the design of the preventive maintenance plans and resources. This design would help in protecting the system from any unexpected losses or failures which means protection from any additional costs and unexpected wasted resources. This would keep the ratio between added resources and output value near the $100 \%$ efficiency. The efficiency is not only about resources but also about time which is discussed in the second element of the group concerning preventive plan, schedule and resources optimization. The main concern of this element is to design preventive plans and schedules to make sure that time is not wasted and the efforts distribution plans are complying with the maintenance schedule. 
However, the third group will be "Assessment". This group consists of two elements where the first element is the maintenance execution assessment and control. This element describes the execution of the maintenance plan according to the objectives needed to be achieved. Also, it describes how to control and monitor the parameters and conditions of this plan which will lead in assessing, analyzing, defining the life cycle of the maintenance plan and the replacement needed to ensure the maximum optimization for the components. Another advantage is, it leads to maximum efficiency level and highest performance for the life-cycle of a project which can be shown in the second group element "Asset life-cycle analysis and replacement optimization".

In order to ensure the continuity of maintenance management model, continuous improvement and new techniques utilization is needed as a main element of the fourth group. It ensures the improvement and durability of the maintenance plan and ensures that this model is updated and improved according to the latest new techniques and technology, to keep up the highest levels of efficiency, effectiveness, and assessment.

\subsection{Benefits of integrating Maintenance Management in the Design Process}

The involvement of maintenance management in the design stage includes lower cost of procurement due to a reduction in design alteration and rework, where every detail and component done in the design will be explained and translated to the cost.

This could be shown in the form of its materials, maintenance method, maintenance companies, ability to find the spare parts in the market, availability of components delivered from abroad and its delivery time. Moreover, the maintenance management view will predict the estimated budget needed in the process of construction and operation according to the design process, provision of a facility that is better suited to the needs of the end user. This facility could be attractive to the potential users and clients, respond to their needs, easy to run, maintain, control and manage [3].

\subsection{Definitions of Building Information Modeling}

According to the researches published lately from 2006 till 2018, a random sample shows that there were different authors defining the building information modeling from their different point of views as shown below in Table 1. 


\begin{tabular}{|c|c|c|c|}
\hline Author & Date & Definition & Remarks \\
\hline Gang [4] & 2006 & $\begin{array}{l}\text { "Comprehensively control all information and organization, } \\
\text { duties and processes needed from the stage of planning for } \\
\text { construction to its cycle of design, construction, } \\
\text { maintenance, and demolition." }\end{array}$ & $\begin{array}{l}\text { Didn't provide the } \\
\text { benefit of cost } \\
\text { estimation which is } \\
\text { one of the important } \\
\text { factors for the } \\
\text { owner. }\end{array}$ \\
\hline NIBS [5] & 2007 & $\begin{array}{l}\text { "Provide a parametric based model to reflect insertion, } \\
\text { extraction, updating or altering physical, functional } \\
\text { characteristics of building at each step as needed throughout } \\
\text { the processes to support cooperation among related parties." }\end{array}$ & $\begin{array}{l}\text { Didn't provide the } \\
\text { benefit of cost } \\
\text { estimation to the } \\
\text { client/owner. }\end{array}$ \\
\hline $\begin{array}{l}\text { Cheol an Shik } \\
\text { [6] }\end{array}$ & 2007 & $\begin{array}{l}\text { "Comprehensively manage and use information on all steps } \\
\text { from planning to expiry through exchanging and sharing } \\
\text { information according to projects, processes focusing on } \\
\text { interoperation of information through the entire lifecycle of } \\
\text { construction." }\end{array}$ & $\begin{array}{l}\text { Didn't provide the } \\
\text { benefit of cost } \\
\text { estimation to the } \\
\text { client/owner. }\end{array}$ \\
\hline GSA [7] & 2007 & $\begin{array}{l}\text { "Building Information Modeling is the development and use } \\
\text { of a multi-faceted computer software data model to not only } \\
\text { document a building design but to simulate the construction } \\
\text { and operation of a new capital facility or a recapitalized } \\
\text { (modernized) facility. The resulting Building Information } \\
\text { Model is a data-rich, object-based, intelligent and } \\
\text { parametric digital representation of the facility, from which } \\
\text { views appropriate to various users' needs can be extracted } \\
\text { and analyzed to generate feedback and improvement of the } \\
\text { facility design." }\end{array}$ & $\begin{array}{l}\text { BIM is considered to } \\
\text { be a system which } \\
\text { can be applied by a } \\
\text { computer } \\
\text { application } \\
\text { (software), it is not a } \\
\text { direct software. }\end{array}$ \\
\hline $\begin{array}{l}\text { Van Nederveen } \\
{[8]}\end{array}$ & 2009 & $\begin{array}{l}\text { "Include complete and sufficient information to support all } \\
\text { lifecycle processes and which can be illustrated directly by } \\
\text { computer applications. It comprises information about the } \\
\text { building itself as well as its components and comprises } \\
\text { information about properties such as function, shape, } \\
\text { material, and processes for the building lifecycle." }\end{array}$ & $\begin{array}{l}\text { Didn't mention that } \\
\text { it is a central virtual } \\
\text { model, the } \\
\text { coordination } \\
\text { between different } \\
\text { disciplines and the } \\
\text { benefit of cost } \\
\text { estimation for the } \\
\text { owner. }\end{array}$ \\
\hline Lahiff [9] & 2012 & $\begin{array}{l}\text { "Building Information Modeling is a digital representation } \\
\text { of the physical and functional characteristics of a facility. It } \\
\text { is a shared knowledge resource for information about a } \\
\text { facility, forming a reliable basis for decisions during its life } \\
\text { cycle, from earliest conception to demolition." }\end{array}$ & \\
\hline
\end{tabular}




\begin{tabular}{|c|c|c|c|}
\hline $\begin{array}{l}\text { Kreider, } \\
\text { Ralph, } \\
\text { Messner, and } \\
\text { John [10] }\end{array}$ & 2013 & $\begin{array}{l}\text { "The act of creating an electronic model of a facility for } \\
\text { the purpose of visualization, engineering analysis, } \\
\text { conflict analysis, code criteria checking, cost } \\
\text { engineering, as-built product, budgeting, and many other } \\
\text { purposes." }\end{array}$ & $\begin{array}{l}\text { It is a process in } \\
\text { which the } \\
\text { electronic model is } \\
\text { applied by } \\
\text { computerized } \\
\text { software }\end{array}$ \\
\hline Denis [11] & 2015 & $\begin{array}{l}\text { "BIM is a process in which different actors work } \\
\text { together, efficiently exchange information (data and } \\
\text { geometry) and collaborate to provide a more efficient } \\
\text { construction process (e.g. fewer errors, faster } \\
\text { construction) but also more efficient buildings that } \\
\text { produce less waste and are cheaper but also easier to } \\
\text { operate. With that vision, the key is not the three- } \\
\text { dimensional modeling itself but the information } \\
\text { developed, managed and shared, in support of better } \\
\text { collaboration." }\end{array}$ & \\
\hline Parn [12] & 2017 & $\begin{array}{l}\text { "BIM displaced traditional approaches and created } \\
\text { virtual communities of practice }(\mathrm{CoP}) \text {. A virtual CoP } \\
\text { represents an extensive 'multiple stakeholder' } \\
\text { collaboration platform that is generated during design } \\
\text { and construction passing through an operational phase in } \\
\text { a single integrated BIM model." }\end{array}$ & \\
\hline $\begin{array}{l}\text { Martínez- } \\
\text { Airesa M. } \\
\text { [13] }\end{array}$ & 2018 & $\begin{array}{l}\text { "BIM could greatly benefit the Architecture, } \\
\text { Engineering, and Construction (AEC) industry as a tool } \\
\text { that contributes to safety management, e.g. through } \\
\text { scheduling, clash detection, construction progress } \\
\text { tracking, design consistency and visualization, data } \\
\text { integration, cost estimations, implementation of lean } \\
\text { construction or improved team member collaboration." }\end{array}$ & $\begin{array}{l}\text { BIM is not a tool it } \\
\text { is a process which } \\
\text { tools are used to } \\
\text { apply this system. }\end{array}$ \\
\hline
\end{tabular}

Table 1. Different definitions for building information modeling (by the researchers)

In the end, BIM could be summarized as a system represented in a comprehensive virtual model simulated from the earlier stage of a project by a computer application ${ }^{1}$, which makes different stakeholders work together as a team in different phases of a project. Also, it can share, analyze and develop specific information of integrated full database of a building. Thus, it can recommend an efficient basis for decisions, which could help in reducing cost, time, rework and avoid any conflicts which could appear in the construction phase.

${ }^{1}$ Computer application or software are computerized programs, which are used to apply building information modeling system such as : Revit, ArchiCad, Navisworks, Bentely, Civil 3D, etc. 


\subsection{History of BIM Standards in Construction Handover (EDMS)}

Before the emergence of building information modeling, there was a standard which supports the delivery process of a project till the operation phase, which is known as Electronic Document Management System (EDMS). However, there were some defects which increase the cost and time of maintenance process, while the technological development and appearance of building information modeling helped in mitigating these defects sequentially as follows:

\subsubsection{Operations and Maintenance Support Information in 1990-s}

A standard was defined by the National Institute of Building Sciences (NIBS), Facility Maintenance and Operations Committee (FMOC) for capturing construction handover data electronically. In this standard, the data structure follows the format defined in the Unified Facility Guide Specifications, Operations and Maintenance Support Information (OMSI) [14].

Per OMSI requirements, indexed contract documents are delivered in both paper and electronic file (PDF) format. Although PDF files that are compiled in one location ffor example a compact disk (CD) $\}$ help to reduce the time spent on retrieving information, they present four major problems:

- The initial OMSI creation cost is too high.

- The information on the CD does not get shared among multiple parties involved in the facility management due to the lack of standardized, centralized data storage.

- The owner pays three times for the construction handover information; first, during design and construction when this information is generated, second, during close-out when paper copies get scanned and compiled in a $\mathrm{CD}$, and third, to operation contractors for surveying existing equipment and compiling information into the owner's computerized maintenance management system (CMMS).

- Difficulty in purchasing replacement equipment that is no longer manufactured due to the lack of information about the original design requirements of such equipment [15].

\subsubsection{The appearance of extensible markup language in $\mathbf{2 0 0 0}$}

National Institute of Building Sciences (NIBS), Facility Maintenance and Operations Committee (FMOC) created an extensible Markup Language (XML) schema that would organize the [pdf] files merged into an OMSI data file. Through this schema, the manufacturer's product data can be imported to the owner's CMMS system directly [16].

\subsubsection{The appearance of Industrial Foundation Class Model in 2002}

In 2002, Industrial Foundation Classes (IFC) data format was tested to discover if it could improve information flow throughout design and construction as well as handover to operations and maintenance. The project was named IFC Model-Based Operations and Maintenance (IFCM-BOM) and it was sponsored by The U.K. Department of Trade and Industry (DTI).

The goal of this pilot project was to demonstrate the IFC's capabilities and encourage commercial software implementations. The project was led by Taylor Woodrow Construction and the technology consultants. The project targeted to eliminate the delay and cost involved in populating maintenance management (MM) system which was estimated to be 6 to 12 months. [17]

The Industry Foundation Classes (IFC) data model describes building and construction industry data and is developed by Building SMART Alliance (International Alliance for Interoperability, IAI) to facilitate interoperability between applications commonly used in AEC industry. IFC file format is object-based with a data model managed by a model server. A model server is a software that enables complete models to be imported and exported and helps real-time data sharing among several software applications. Therefore, IFC is designed to be a neutral and open specification that is not controlled by any specific vendor.[18]

For this test project, a two-story auditorium within a community college building was chosen and only the data related to the building services (mechanical, electrical, plumbing) was transferred. The project team created a building information model of the building services using a number of software applications and based on the $2 \mathrm{D}$ drawings created by the original design team. 
The team generated a package including schedules of the spaces and mechanical systems that included instances, types and operational instructions for handover. Then, they loaded the assets' information into a Commercial Asset Management System. The package and the loaded information were organized around the room requirements data that was taken from the room sheet information, which was created by the client and the architect. The generation of the package and the data load were completed in a few minutes, fully automatically without any re-keying. [17]

\subsubsection{National Building Information Model Standard effort in 2005}

After the success of this test project, National Building Information Model Standard effort was formed to develop and encourage the adoption of information exchange standards based upon the IFC models [19].

\subsubsection{Initiation of Construction Operation Building information exchange in 2006}

In December 2006, the Construction Operations Building Information Exchange (COBie) project was initiated to identify a completely electronic information exchange process between design and construction deliverables of a facility and its operation and maintenance system. As a result of this effort, several data elements that are critical for maintenance of a facility such as location, rooms' area, warranty periods, parts suppliers, and equipment data were identified. This data can be captured electronically and be imported to CMMS systems that support a standard data format which is IFC-compliant. [17]

\subsubsection{Implementation of COBie in 2007}

In 2007, the COBie Pilot implementation standard was published as Appendix B of the National Building Information Model Standard. Since then, several federal agencies such as the General Services Administration, the US Army Corps of Engineers, Department of State's Overseas Building Operations, National Aeronautics and Space Administration, and the Departments of Veterans Affairs contractually require the delivery of COBie data. In the first COBie implementation report published in 2008, Fort Lewis Department of Public Works reported that COBie could save them one full-time data entry clerk and reduce by half the need for a full-time CAD operator (NBIMS US COBie v2 ballot submission).

As the positive outcomes of this process get widely reported, many large private owners have started looking for the implementation of COBie in their projects as well. In a COBie case study presentation, a hospital maintenance manager stated that they could reduce the handover process from 3 man-years to 3 minutes by using COBie (NBIMS US COBie v2 ballot submission). In addition to the owners, commercial software providers have increased their efforts in generating software applications that will support COBie. [20]

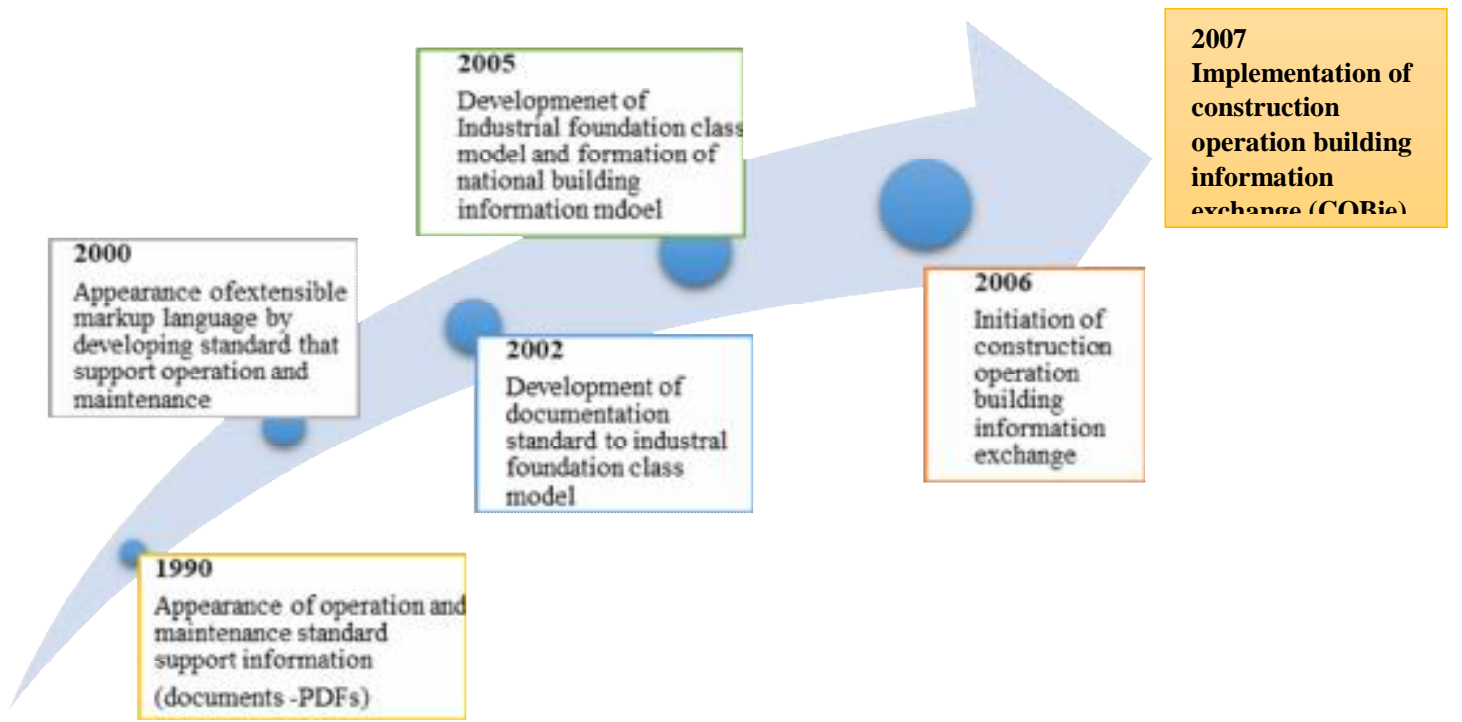

Figure 2. Graphical Timeline shows the development of EDMS [by the researchers]. 
This was evidenced by the several vendors' presentation in BIM and Maintenance Management in conference 2012 BIM Forum. In the COBie Guide published in October of 2012, it is reported that over twenty commercial software products that cover the entire facility life-cycle from planning, design, construction, commissioning to operations, maintenance, and space management support COBie [21].

Currently, the data required for COBie implementation gets compiled in the building information model (BIM) or spreadsheets in the close-out of the construction by the general contractor. However, this is not the best practice as the data is not captured by the party that has created it, in other words, the data has been created by either the designers or the manufacturers but is compiled and entered into the BIM by the general contractor which presents inefficiency in the system.

Capturing COBie data as it gets created, which will essentially require designers and manufacturers to format it electronically will increase accuracy and eliminate general contractor's fee for providing such services. In order to achieve these objectives, it is necessary that the building industry drafts contracts that will support COBie implementation across all parties involved in the project [14].

\subsection{The process of Integrating BIM with Maintenance Management}

As mentioned before, maintenance is defined as the activities required to keep a facility in asbuilt condition, while continuing to maintain its original productivity. During this procedure, identifying the component location, getting the relevant documents and maintenance information should be carried out by maintenance managers and their staff for the component subjected for it.

Also, knowledge and experience of maintenance managers play a role in informing architectural designers with their requirements, both interior and exterior requirements should be considered for normal installation and implementation, so that BIM could produce all the abovementioned information and requirements in a graphical interface. This could make it easier for designers and maintenance managers to make the optimum decisions. [22]

Additionally, MM personnel could get the relevant data of a task from BIM's graphical interface in a realistic time. Conventionally, they have to $\log$ on to different electronic document management systems (EDMSs) and toggle it between multiple databases to get the required information.

Thus, integration of BIM with maintenance has solved a critical problem, where BIM helps in making electronic storage by saving each component with its full specs as explained in COBie standard. This can help in saving time, resources and method of exporting the information needed will be easier [23]. However, the below table shows some of the benefits of using BIM for maintenance managers.

Table 2. Potential benefits of using BIM for project and maintenance managers [22] and [23].

\begin{tabular}{|l|l|l|}
\hline Author & $\begin{array}{c}\text { The potential benefit for } \\
\text { MMs }\end{array}$ & \multicolumn{1}{c|}{ Description of potential benefits } \\
\hline $\begin{array}{l}\text { Eastman } \\
(2011)\end{array}$ & $\begin{array}{l}\text { Organize the project } \\
\text { schedule and budget }\end{array}$ & $\begin{array}{l}\text { An integrated 7D BIM model immediately updates } \\
\text { both the schedule and budget when any design change } \\
\text { occurs. }\end{array}$ \\
\hline $\begin{array}{l}\text { Eastman } \\
(2011)\end{array}$ & $\begin{array}{l}\text { Work well with the design } \\
\text { team }\end{array}$ & $\begin{array}{l}\text { By using the integrated 7D BIM model to visualize } \\
\text { and explore the impact of changes, s/he can keep the } \\
\text { project's scope in check and become a trustworthy } \\
\text { connection between designers, maintenance managers, } \\
\text { and owner. }\end{array}$ \\
\hline $\begin{array}{l}\text { Eastman } \\
(2011)\end{array}$ & $\begin{array}{l}\text { Hiring and controlling } \\
\text { subcontractors }\end{array}$ & $\begin{array}{l}\text { Having a handle on clash detection and coordination } \\
\text { plays a key role in keeping sub-contractors' work } \\
\text { predictable. }\end{array}$ \\
\hline $\begin{array}{l}\text { Becerik } \\
\text { Gerber } \\
(2011)\end{array}$ & $\begin{array}{l}\text { Request for information } \\
\text { (RFIs) and change orders }\end{array}$ & $\begin{array}{l}\text { Utilizing coordination resolution in preconstruction, } \\
\text { these numbers can be brought to near zero. }\end{array}$ \\
\hline
\end{tabular}




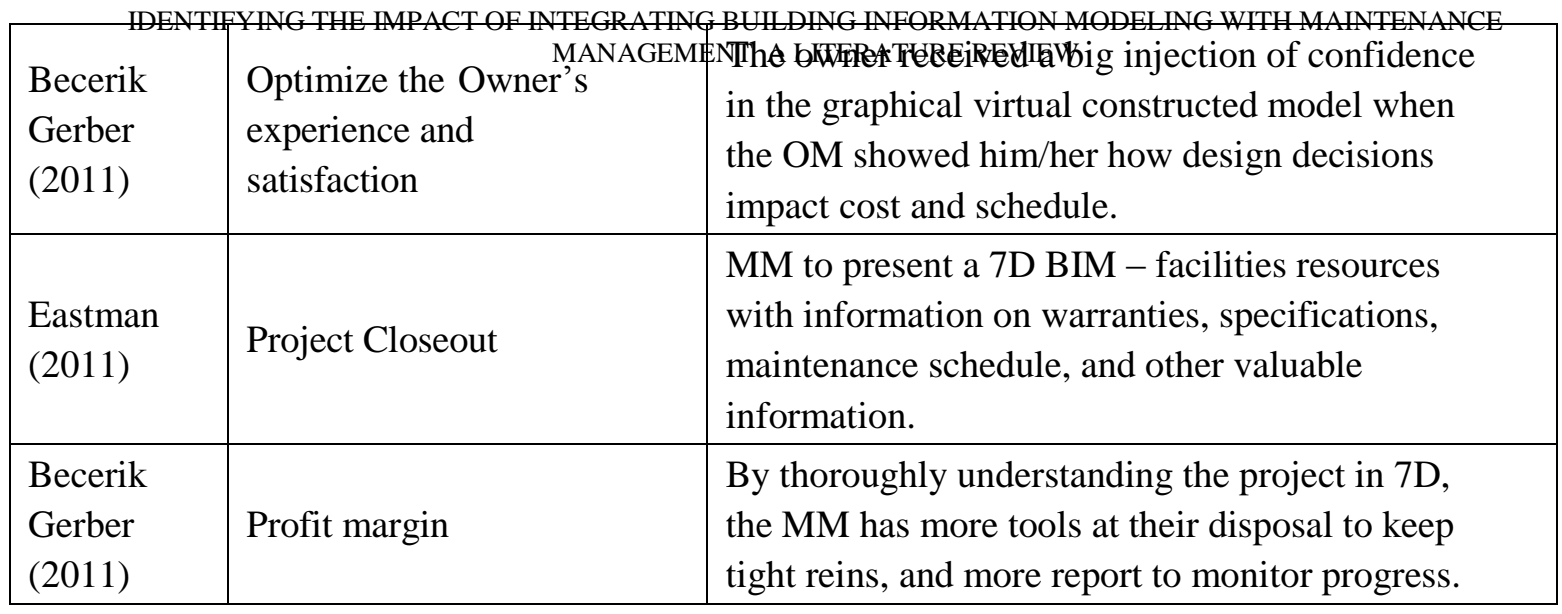

Table 2. shows that integration of BIM with MM helps in controlling both the budget and schedule of a project, and can have successful coordination with other stakeholders through the virtual model with specific information avoiding any clashes. Accordingly, the contractor's requests for information (RFI) would be neglected.

In the end, all of these benefits could be merged and easily explained to the owner and show him the total imagination of the project and its impact from design phase passing through construction phase till the operation phase.

Figure 3. shows the interaction between BIM, maintenance team and project manager, where BIM database is formed from work order ID, facility ID, location, description of preventive work, documents required to perform maintenance, estimated and actual hours and frequency of maintenance work. Where these data could be integrated into BIM as attributes and documents.

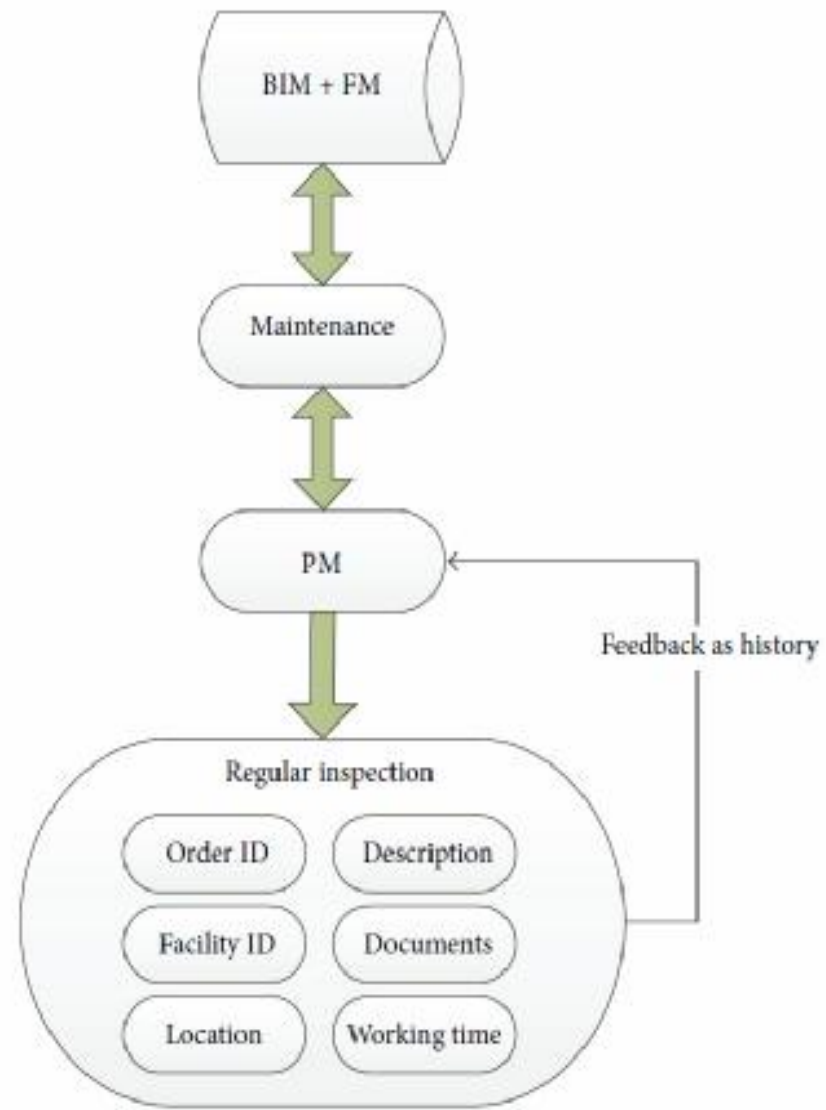

Figure 3. BIM based PM Workflow [24]. 
In addition, time of maintenance, status information and working hours are sent to BIM as feedback after each maintenance process and to be considered as a reference for the next maintenance process. Also, all maintenance information such as location, relevant maintenance history could be accessed conventionally, which will make future maintenance reasonable and prevent redesigning. [24]

\subsection{The Incorporation of BIM-Based Tools with Maintenance Management}

BIM tools ${ }^{2}$ allow maintenance managers with software tools, which offer them structured support with integrating scope, time, and cost of a project plan in a way that was not easily possible earlier.

First, the application of BIM-based tools reduces the time that managers need to spend on some of the labor-intensive tasks. BIM-based tools, for example, decrease the time for managers to take off the quantities to generate the bill of materials, schedule, and its cost estimation. [11]

While integrating BIM-based tools help in reducing the time of managers needed in collecting and keying the data manually. Also, with the technological development, BIM-based tools allow using several project management tools in one project. For example, BIM-based tools allow the integration of traditional critical path method (CPM) Gantt chart visualization methods of schedules with 4D visualizations and line-of-balance visualizations. [10]

At the same time, maintenance managers would find difficulty in learning different methods of maintenance using traditional tools, which don't depend on smart BIM database, hence, maintenance managers would traditionally translate these methods and present them one by one with each modification in an isolated way, leading to rework, wasting time and cost.

On the other hand, using BIM-based project management software give maintenance managers the ability to use different methods from one data source, so that time could be saved, the cost could be reduced with warranty of best quality and performance could be produced from the data gathered.

While at the construction phase, project plans change according to the conditions of the existing environment. So management plays a role in merging these changes at a constructed project with respect to time-saving, where BIM-based tools support automatic update for changes by storing relations between scope, task, time and cost. Keeping a project plan updated and on the right track with all changes happened.

Finally, all the above-mentioned advantages together give maintenance managers the right to optimize project plans, better design, calculate schedules, visualize project plan information and estimate it. Allowing them to find wrong assumptions, bottlenecks and any other shortage in their project plan. [10]

Additionally, BIM-based maintenance management tools allow managers to automatically change any part of the project plan and see the consequences on the other parts, in spite of the limited time and resources, it can make different alternatives to mitigate shortage discovered. Overall this functionally was not possible before. [9]

Furthermore, BIM-based maintenance management tools allow maintenance managers with the following [9]:

2 BIM tools are supposed to be a group of software applications made by several companies which are supporting all BIM team including BIM team coordinators and maintenance managers to save time during work, reduce cost and make the quality of productivity at its high efficiency. 
1. The use of existing project cases with minimum time required.

2. The combined teaching of different integration methods for project planning information.

3. Merging all the changes in management tasks.

4. Increasing the opportunities to use project plan optimization.

\subsection{Benefits of Integrating BIM for Maintenance Managers}

From the advantages of BIM is that it can be used at all stages of a project life-cycle, where the owner can understand project needs, the design team will be able to analyze, design different proposals and develop a project, while managing the construction will be the responsibility of the contractor. Finally, maintenance managers will play a role at the operation and maintenance phase by implementing maintenance schedules and create the database for the components of a project which would be used at any time after operating a project.

Other benefits for BIM, it could simulate virtual model before its construction and undertaken for real, where BIM will be able to analyze different scenarios according to the performance of a building through its life cycle. As a result, utilizing project with BIM could virtually be built several times, which gives maintenance managers the ability to re-engineer their process to reach the best integration of different stakeholders, schedules, plans and database in the construction projects.

Ending with seven pillars could be produced from implementing BIM, which are: eliminate waste, increase feedback, delay decisions to obtain the best proposal, deliver fast, build-in integrity, empower the team and see the whole as shown in Figure 5. Accordingly, better outcomes and outputs will be achieved by maintenance managers, and they will have a better effect on the resourcing of a project team by using BIM [22].

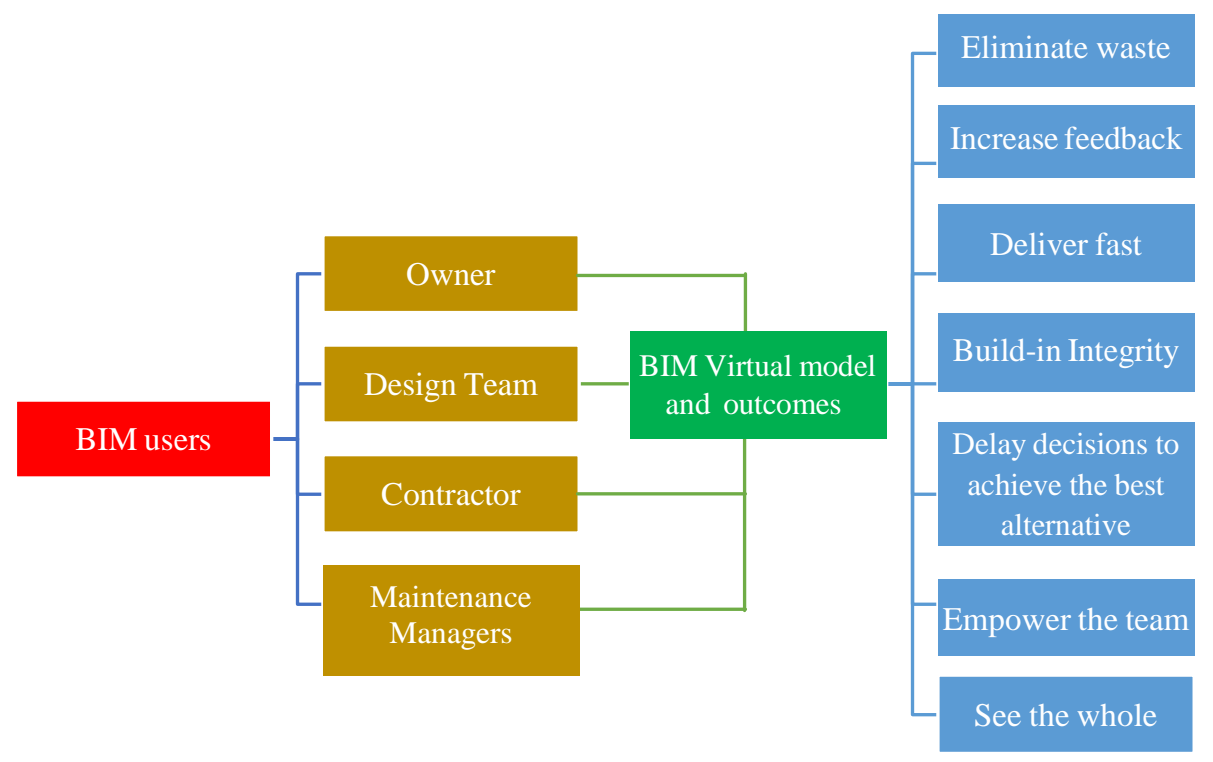

Figure 5. Benefits of integrating maintenance managers with BIM [22]. 


\subsection{Findings}

\subsection{The Role of BIM in Supporting MM}

Maintenance managers can reach higher quality and better performance of buildings by using BIM tools and processes, which is considered to be one of the important benefits of it, where collaboration between project parties can reduce errors and field changes. Therefore, it helps reducing project time and cost during the delivery process. In this regard, there are several potential contributions for BIM where maintenance managers can use them such as:

- Increasing a building value through BIM-based energy design and analysis for improving overall building performance.

- $\quad$ Shorting project schedule from approval to completion by using building models to coordinate and prefabricate design with reduced field labor time.

- Obtaining reliable and accurate cost estimates through automatic quantity take - off from the building model, providing feedback earlier in a project when decisions will have the greatest impact.

- Assure program compliance through ongoing analysis of the building model against the owner and local code requirements.

- $\quad$ Produce market ready for facilities use by reducing the time between procurement decisions and actual construction, allowing for a selection of the latest technologies or trend finishes [7].

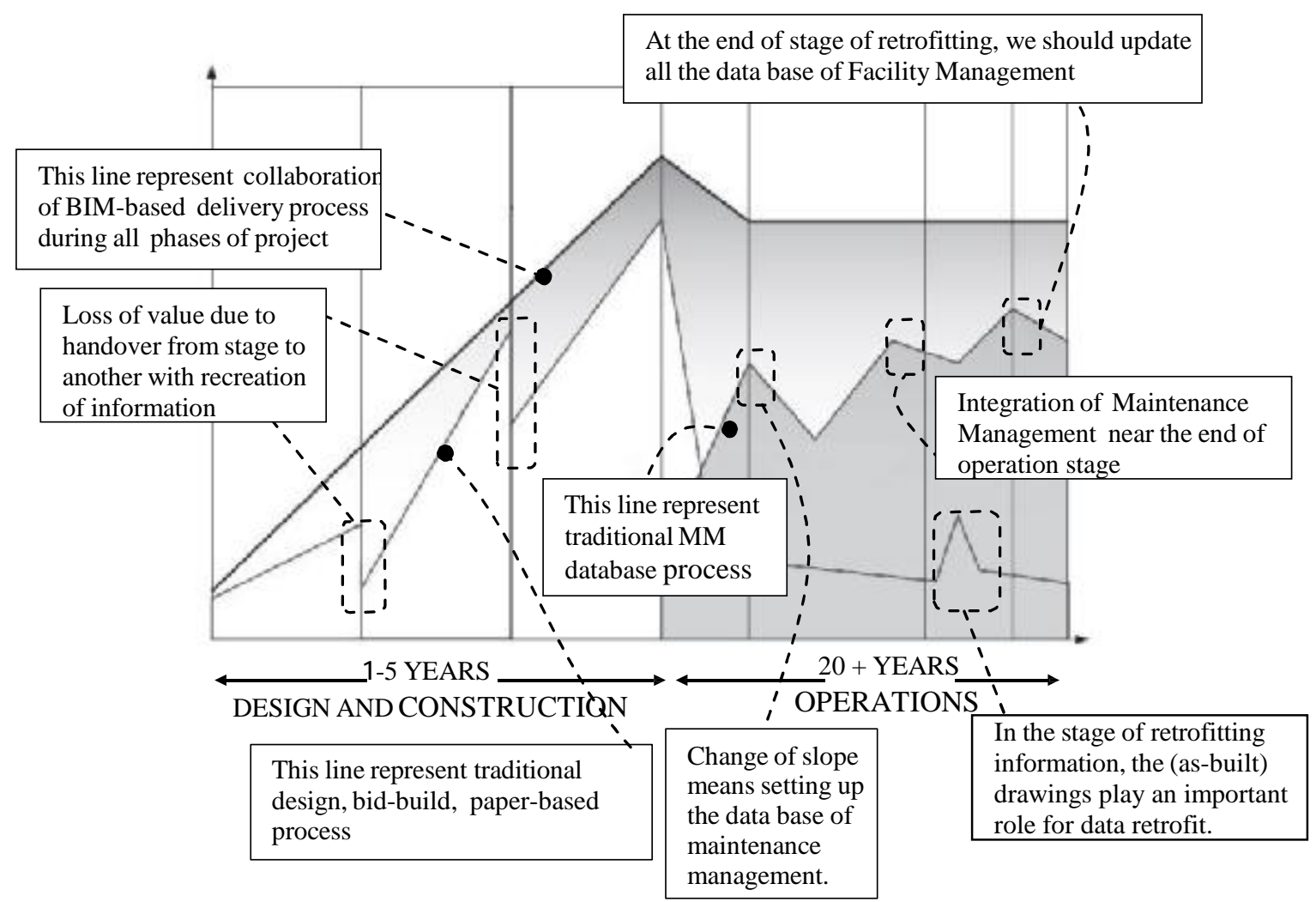

Figure 4. BIM through life cycle compared with traditional way. [7] 


\subsection{Data and Process Required to Support BIM-Enabled Maintenance Management}

BIM can support maintenance management according to its challenges by gathering data required and defining who is responsible to provide these data on the life cycle of a project, determining when these data should be used and needed, latterly, discussions showed that there are several data required for BIM that should be collected and provided for implementing maintenance management such as [4]:

- Accurate as-built models of all building components, including architectural, structural, mechanical, electrical, plumbing, fire protection systems and site plan including safety accesses.

- $\quad$ Accurate as-built model for main utility lines to the buildings.

- Accurate telecommunication representations including proper placing and annotation of outlets.

- $\quad$ Labeled, annotated and colored spaces according to MM guidelines, which should include standards for space type, description, and space usage.

- $\quad$ Built-in schedules in the model.

- $\quad$ Logical object tree organization to manage the various components within the model.

- $\quad$ Accurate clearance requirements for MEP equipment in order to provide maintenance based on technical specifications.

\subsection{CONCLUSION}

From all the previous discussions, BIM is considered to be one of the best technological systems that supports the AEC industry. Where the potential of BIM in achieving better coordination, detection of clashes and time and resources savings, starting from design phase passing through the construction phase and till operational phase.

Meanwhile, this paper shows that using Construction Operation Building Information Exchange (COBie) as a one of BIM tools could help maintenance managers and staff, where this standard or handover method proved that it could generate a database full of accurate information for each component used in a building, taking in consideration that this standard needs to be implemented and start with the beginning of design phase.

In addition, it showed that COBie could eliminate the traditional methods of documents handover, where it can provide the needed information upon request by fewer resources and eliminating waste of time in generating the information needed, sequentially this might led to reducing the cost of maintenance budget and indirect cost of a project.

Furthermore, COBie standard supports preventive maintenance, which helps in keeping a building with its high efficiency and performance. In order to mitigate any sudden failures to the components in a building and affect its function.

These conclusions are considered to be the results of the intensive research work and analysis for the situation of maintenance management and BIM standards. However, these results aren't covering the whole picture and sides of this topic. These sides are recommended to be investigated in further and deeper research in order to show the biggest picture of this topic. 


\section{REFERENCES}

[1] De Marco, A., Mangano G. (2012). A Review of the Role of Maintenance and Facility Management in Logistics. London, International Association of Engineers.

[2] Marquez, A. (2006). Contemporary maintenance management: process, framework and supporting pillars. Omega The International Journal of Management Science, pages 313326.

[3] Allen, D. (1993), What Is Building Maintenance. Facilities, Vol. 11 (Issue 3), pages 7 - 12.

[4] Gang, L. (2006). Key Technology for Managing Building Lifecycle. Korea, Korean Architect Academy.

[5] National Institute of Building Sciences (NIBS). (2007). Part 1: Overview, Principles and Methodologies in National Building Information Modeling Standard. United States, C .M. Eastman.

[6] Cheol, L. S. (2007). Study on the development of construction duty integration model through analysis on BIM cases. Korea, Korean Architect Academy.

[7] General Services Administration. (2007). Series 01 - Overview, in GSA Building Information Modeling Guide. Washington, DC.

[8] Van Nederveen, S., Behesshti, R. (2009) Concepts and Technologies on Building Information Modeling and Construction Informatics. United States, New York: IGI Global.

[9] Lahiff, B. (2012). BIM an introduction for Engineers. Ireland, Association of Consulting Engineers of Ireland.

[10] Kreider, R. G. and Messner, J. I. (2013). The Uses of BIM: Classifying and Selecting BIM Uses. The United States, The Pennsylvania State University.

[11] Denis, F. (2015). A Framework Supporting Designers In Creating Custom Data-Enabled Tools. Belgium, Free University of Brussels.

[12] Parn, E. (2017). The building information modeling trajectory in facilities management: A review. Automation in Construction Journal, pages 45-55.

[13] Martínez-Airesa, M. (2018). Building information modeling and safety management: A systematic review. Safety Science Journal, pages 11-18.

[14] East, W. B. (2007). BIM for construction handover. Journal of Building Information Modeling, pages 3-4.

[15] East, W. (2011). Construction Operation Building Information Exchange (COBie). Engineer Research and Development Center, U.S. Army, Corps of Engineers.

[16] East, E. W., Nisbet, N., \& Liebich, T. (2013). Facility management handover model view. Journal of Computing in Civil Engineering, pages 61-67.

[17] Commerce Department of National Institute of Standards and Technology, (2010). BIM Standard in Construction Handover. United States, David Wineland.

[18] Building Smart Alliance-National Institute of Building Sceince, (2011). What is Construction Operation Building Information Exchange. United States, John Messner.

[19] Jordani, D. (2010). BIM and FM: The Portal to Lifecycle Facility Management. Journal of Building Information Modeling, Spring 2011, pages 11-18.

[20] Forns-Samso, D.F. (2010). Perceived value of building information modeling in facilities operations and maintenance. Albuquerque, New Mexico: The University of New Mexico.

[21] East, W. B. (2012). BIM for construction handover. Journal of Building Information Modeling, Volume 2.

[22] Eastman, C. (2011). BIM Handbook: A guide to building information modeling for owners, managers, designers, engineers and contractors. The United States, John Wiley \& Sons.

[23] Becerik-Gerber, B., F. J. N. L. G. C. (2011). Application Areas and Data Requirements for Bim-Enabled Facilities Management. Journal of Construction Engineering and Management, Page 21.

[24] Alder, A. (2006). Comparing time and accuracy of building information modeling. Provo, Brigham Young University. 